\title{
Investigating the relationship between hidden curriculum and academic optimism in upper secondary school students
}

\section{Investigando a relação entre currículo oculto e otimismo acadêmico nos alunos do ensino médio}

\section{Investigando la relación entre el currículo oculto y el optimismo académico en estudiantes de secundaria superior}

\author{
Fatemeh Kariman $^{1}(\mathrm{D})$, Soolmaz Nourabadi ${ }^{1}$ \\ ${ }^{1}$ Department of Educational Sciences, Shahed University, Tehran. Iran. \\ Corresponding author: \\ Soolmaz Nourabadi \\ Email: nourabadi@shahed.ac.ir
}

How to cite: Kariman, F., \& Nourabadi, S. (2021). Investigating The Relationship Between Hidden Curriculum and Academic Optimism in Upper Secondary School Students. Revista Tempos e Espaços em Educação, 14(33), e16086. http://dx.doi.org/10.20952/revtee.v14i33.16086

\begin{abstract}
This study aimed to determine the relationship between hidden curriculum and academic optimism in upper secondary school students. The research method was descriptive-correlational. The statistical population of this research consists of upper secondary school students of Pakdasht city in the academic year 2020-2021 with 3500 people. The sample size was determined based on Krejcie and Morgan table of 346 people. Also, for sampling, after estimating the sample size, the available random sampling method was use. In order to collect data, two standardized questionnaires were used for assessing the hidden curriculum (Fathi Vajargah) and the questionnaire for assessing academic optimism (Schennemoran). Descriptive statistics methods including: mean, percentage and frequency and inferential statistics such as: Pearson correlation test, one-sample t-test and multiple regression were used. SPSS22 was also used to analyze the collected data. The findings of Pearson correlation coefficient indicated that there is a significant relationship between the hidden curriculum and the academic optimism of the studied students at the alpha level of 0.01 . Findings of one-sample t-test indicated that the students surveyed were at a relatively good level in terms of the components of academic optimism as well as the hidden curriculum. The results of correlation test showed that there is a significant relationship between the two components of the hidden curriculum (school social atmosphere and teacher-student interactions) with students 'academic optimism, but the findings showed that there isn't any relationship between school organizational structure and students' academic optimism. The correlation coefficient also showed that there is a significant and direct relationship between the hidden curriculum and all components of students' academic optimism. Also, the findings of
\end{abstract}


regression test indicated that the latent hidden curriculum variable explains 0.28 variance of academic optimism of the students and only the organizational structure of the school did not play a significant role in predicting students' academic optimism. Also, the findings of the regression test indicated that among components of hidden curriculum, the component of teacher-student interactions had the largest share in explaining and predicting changes in students' academic optimism.

Keywords: Hidden Curriculum. Teacher-Student Interactions. School Social Atmosphere. Academic Optimism.

\section{RESUMO}

Este estudo teve como objetivo determinar a relação entre currículo oculto e otimismo acadêmico em alunos do ensino médio. O método de pesquisa foi descritivo-correlacional. A população estatística desta pesquisa consiste em alunos do ensino médio da cidade de Pakdasht no ano acadêmico de 2020-2021 com 3.500 pessoas. O tamanho da amostra foi determinado com base na tabela Krejcie e Morgan de 346 pessoas. Além disso, para a amostragem, após estimar o tamanho da amostra, foi utilizado o método de amostragem aleatória disponível. Para a coleta de dados, foram utilizados dois questionários padronizados para avaliação do currículo oculto (Fathi Vajargah) e o questionário para avaliação do otimismo acadêmico (Schennemoran). Métodos de estatística descritiva incluindo: média, porcentagem e frequência e estatísticas inferenciais como: teste de correlação de Pearson, teste t para uma amostra e regressão múltipla foram usados. O SPSS22 também foi usado para analisar os dados coletados. Os achados do coeficiente de correlação de Pearson indicaram que existe uma relação significativa entre o currículo oculto e o otimismo acadêmico dos alunos estudados no nível alfa de 0,01 . Os resultados do teste t de uma amostra indicaram que os alunos pesquisados estavam em um nível relativamente bom em termos dos componentes do otimismo acadêmico, bem como do currículo oculto. Os resultados do teste de correlação mostraram que existe uma relação significativa entre os dois componentes do currículo oculto (ambiente social escolar e interações professor-aluno) com o otimismo acadêmico dos alunos, mas os achados mostraram que não há relação entre a organização escolar estrutura e otimismo acadêmico dos alunos. O coeficiente de correlação também mostrou que existe uma relação significativa e direta entre o currículo oculto e todos os componentes do otimismo acadêmico dos alunos. Além disso, os resultados do teste de regressão indicaram que a variável do currículo oculto latente explica 0,28 da variância do otimismo acadêmico dos alunos e apenas a estrutura organizacional da escola não desempenhou um papel significativo na previsão do otimismo acadêmico dos alunos. Além disso, os resultados do teste de regressão indicaram que, entre os componentes do currículo oculto, o componente das interações professor-aluno teve a maior participação na explicação e previsão de mudanças no otimismo acadêmico dos alunos.

Palavras-chave: Currículo Oculto. Interações Professor-Aluno. Atmosfera Social Escolar. Otimismo Acadêmico.

\section{RESUMEN}

Este estudio tuvo como objetivo determinar la relación entre el currículo oculto y el optimismo académico en estudiantes de secundaria superior. El método de investigación fue descriptivocorrelacional. La población estadística de esta investigación consiste en estudiantes de secundaria superior de la ciudad de Pakdasht en el año académico 2020-2021 con 3500 personas. El tamaño de la muestra se determinó con base en la tabla de Krejcie y Morgan de 346 personas. Asimismo, para el muestreo, luego de estimar el tamaño de la muestra, se utilizó el método de muestreo aleatorio disponible. Para la recolección de datos, se utilizaron dos cuestionarios estandarizados para evaluar el currículo oculto (Fathi Vajargah) y el cuestionario para evaluar el optimismo académico (Schennemoran). Se utilizaron métodos de estadística descriptiva que incluyeron: 
media, porcentaje y frecuencia y estadísticas inferenciales como: prueba de correlación de Pearson, prueba t de una muestra y regresión múltiple. También se utilizó SPSS22 para analizar los datos recopilados. Los hallazgos del coeficiente de correlación de Pearson indicaron que existe una relación significativa entre el currículo oculto y el optimismo académico de los estudiantes estudiados en el nivel alfa de 0.01 . Los resultados de la prueba t de una muestra indicaron que los estudiantes encuestados estaban en un nivel relativamente bueno en términos de los componentes del optimismo académico, así como del plan de estudios oculto. Los resultados de la prueba de correlación mostraron que existe una relación significativa entre los dos componentes del currículo oculto (ambiente social escolar e interacciones maestro-alumno) con el optimismo académico de los estudiantes, pero los hallazgos mostraron que no existe relación entre la organización escolar estructura y optimismo académico de los estudiantes. El coeficiente de correlación también mostró que existe una relación significativa y directa entre el currículo oculto y todos los componentes del optimismo académico de los estudiantes. Además, los hallazgos de la prueba de regresión indicaron que la variable curricular oculta latente explica la varianza de 0.28 del optimismo académico de los estudiantes y solo la estructura organizacional de la escuela no jugó un papel significativo en la predicción del optimismo académico de los estudiantes. Además, los hallazgos de la prueba de regresión indicaron que entre los componentes del currículo oculto, el componente de las interacciones maestro-alumno tuvo la mayor participación en la explicación y predicción de cambios en el optimismo académico de los estudiantes.

Palabras clave: Currículo oculto. Interacciones profesor-alumno. Ambiente social escolar. Optimismo académico.

\section{INTRODUCTION}

Today, educational systems seek to educate people to institutionalize their goals and ideals in them, and a large part of these goals are achieved through educational systems. Thus, the curriculum can provide the conditions and environment for students to learn the way of life while gaining the necessary information and gain life experience in this way (Lippmann, 2019). But research findings show that information and values are not only transmitted through explicit and explicit curriculum, but also more through hidden curriculum (Anderson, 2017). Therefore, one of the most important and successful topics and concepts is the Hidden Curriculum that has a tremendous and undeniable effect on the teaching-learning process. The term hidden curriculum was first introduced by Phillip Jacksum in textbooks and classrooms (Fassih, 2016). This curriculum is considered as a capacity that has multiple functions and seeks to accommodate all hidden educational events as well as the form of implementation of educational expectations and goals. Undoubtedly, one of the most important components in the academic progress of students in school is the hidden curriculum. Students through curricula, especially hidden curriculum are introduced with a variety of scientific, social, historical, economic and political knowledge; and with different skills and attitudes such as respect, honesty, open-mindedness, empathy, patriotism, commitment and responsibility, attention to public interest, equality, observance of law and regulations (Amini \& Saeedkia, 2018).

It can be acknowledged that educational organizations are one of the main institutions in any society and optimal functions of them are considered desirable for any society. Achieving the goals of any military, including educational institutions, depends on a number of interrelated factors. To increase productivity and optimize results, it is necessary to pay attention to other factors in all components of the system. One of these factors is the hidden curriculum, which has great importance in educational systems. The curriculum, as one of the mandatory pillars of the structure of educational sciences, has played an irreplaceable role in educational practices. It has even stepped out of the realm of formality and embraced informal processes. Undoubtedly, one of 
the most important components in fostering students' social education in school is the hidden curriculum (Norouzi et al., 2014).

Although in recent decades the concept of hidden curriculum need to pay attention because it has played a pivotal and special role in curriculum studies and research, in the country. Usually the main focus of our education and researchers has been the formal curriculum. Therefore, a significant part of the curricula that students are actually exposed to in educational systems has been neglected especially the strong effect of the hidden curriculum caused by the school social environment on students. Teaching and learning process is one of the major topics that are considered by experts in educational affairs. Numerous dimensions and factors in this field have been discussed and considered. Many factors such as family, social and political status of individuals, personality traits, and peer group can affect students' learning. But it can be boldly said that the most influential factor in teaching and learning of students is the hidden curriculum and also having a high level of academic optimism. It should be noted that the key role of the hidden curriculum in learning and ultimately students' academic achievement is undeniable (Alikhani and Mehr Mohammadi, 2017).

In other words, one of the opportunities and programs that provide students with an active and lively presence in educational activities and provide the ground for the emergence of their potential capabilities is hidden curriculum with dimensions and components. It can play an important role in social development as well as improving the level and quality of their learning and education. Hidden curriculum using practical and basic components (teacher-student interactions, school social atmosphere, school organizational structure) in the field of education and training can be a big step towards effective participation of students in group activities, educational and learning programs and activities and also pave the way for the entry of this huge and influential group in various cultural, social, political and economic fields of society (Dekel, 2018).

Another focus of this study is academic optimism. The role of academic optimism in the field of education that has been widely considered by education thinkers. Researches has shown that several factors, including students' scientific and academic optimism in educational organizations, play a role in turning learners into creative and innovative people. One of the new concepts that has been considered by education researchers in recent years is the emerging structure of Academic Optimism (Kulophas, 2018). Scientific optimism was first proposed by Hoy, Tarter \& Woolffolk (2006) that they tested and confirmed academic optimism as a property of the school that affects students' academic achievement as a scientific belief and identified some related variables and proposed the structure of Student Academic Optimism (Jasovsky, 2016). Therefore, educational success depends to a large extent on the efforts of that organization in raising the level of academic optimism in order to improve the quantitative and qualitative scientific level of their learners, and this effort will reach the desired level when learners have a significant level of individual academic optimism (Andrew, 2015).

It should be noted that the issue of academic optimism and what factors cause academic optimism, has been one of the challenges for experts, managers and employees of the educational systems (Peterson, 2017). Research has shown that students who have a positive and higher level of optimism, will have a direct impact on their academic achievement as well as their educational and scientific performance. For this reason, many studies and researches on this factor have been done in order to improve the quantitative and qualitative level of efficiency and effectiveness of students' learning; and as a result, many models have been presented. Among the variables and components that lead to academic optimism in students are identified, but while the importance of each of the factors presented, no precise work has been done to accurately differentiate them and prioritize those that play a more influential role. Many education experts believe that the hidden curriculum plays a major role in the development of education and consequently the progress of societies, and therefore special attention should be paid to it. Also, during the past 
years, various approaches have been proposed to change the learning-teaching process, among which we can mention academic optimism and its factors (Mirtorabi, 2017).

Now, according to the studies that have been done and the role of hidden curriculum that can play in the education, academic achievement, and academic motivation of students, as well as according to what has been presented in the previous articles about the hidden curriculum and its various effects and dimensions. So this study intends to study this curriculum and its constituent elements (teacher-student interactions, social atmosphere, physical structure) in upper secondary school students in order to create more knowledge about how this type of curriculum works in schools and among students that will provide a basis for paying more attention to aspects of education and learning and academic optimism of students in this course. Also, since academic optimism is extremely important in this age group, the curriculum can play a significant role in nurturing and developing social and scientific education in students.

\section{RESEARCH QUESTIONS}

1- Are the students at the desired level in terms of academic optimism (by components)?

2- Are the students at the desired level in terms of hidden curriculum (by components)?

3- Is there a significant relationship between teacher and student interactions with students' academic optimism?

4- Is there a significant relationship between school social atmosphere and students' academic optimism?

5. Is there a significant relationship between school organizational structure and students' academic optimism?

6. Is there a significant relationship between the hidden curriculum and each of the components of students' academic optimism?

7. Do hidden curriculum components explain the significant variance of students' academic optimism variables?

\section{METHODOLOGY}

The present study is applied research in terms of purpose. In this research, the researchers seeks to investigate the relationship between research variables. Therefore, this research is descriptive-correlational in terms of data collection method. The statistical population of the present study consists of 3,500 upper secondary school students in Pakdasht city in the academic year of 2019-2020. The sample size was estimated to be 346 according to the statistical population and based on Morgan table. Also, after estimating the sample size, the available random sampling method was used to sample.

The first tool used in this research is the hidden curriculum questionnaire. This tool has been designed by FathiVajargah (2012) in 29 items and in a five-point Likert scale. The tool evaluates the three components of the hidden curriculum (school social atmosphere, school organizational structure, teacher-student interactions) respectively. Also Schennemoran (2016) Academic Optimism Questionnaire was used to measure students' academic optimism. The questionnaire is a closed-ended questionnaire and is designed in a five-point Likert scale. The questionnaire has 28 items and three subscales of students' academic emphasis (8 items), students' trust in teachers (10 items) and students' sense of identity towards school (10 items).

Also in this research, SPSS22 software has been used for data analysis. First, KolmogorovSmirnov test (K-S) was used to check the normality of the data. To test the research questions using inferential statistical methods, and due to the normal distribution of data from was used Pearson correlation test (for questions 3-4-5-6), one-sample t-test (for questions 1 and 2) and linear regression (To examine question 7 ). 


\section{FINDINGS}

In order to analyze the first question of the research: to determine the academic optimism of students (by components), were used one-sample t-test and standard deviation. The results indicated that the academic optimism of the students was relatively good and was significant the status of this variable. The results also showed that the component of students' academic emphasis was not statistically significant. The average obtained for other components also shows that all these components are in a relatively good condition. As a result, with considering the relatively desirable level of academic optimism of upper secondary school students, the reason for this is lack or reduction of the principal's influence in the education area, sufficient and available resources, flexibility of school structure, acceptable level of morale students in schools, almost appropriate age of teachers, high qualifications of teachers, led to improved teacher academic performance and increased academic optimism among students.

To answer the second question: determining the status of the study population in terms of hidden curriculum (by components) was done as in the previous case. Inferential findings showed that the status of this variable based on the obtained data is at a relatively favorable level. Findings showed that the status of perceived hidden curriculum components based on t-score for strategies (school social atmosphere and teacher-student interactions) were significant at 5.55 and 2.92, respectively, at the alpha level $(p<0.01)$. Only the component of school organizational structure (0.67) was not statistically significant, which can be found in the hidden curriculum strategies; teacher-student interaction strategy, average of 3.11 and standard deviation of 0.505 , the highest average among curriculum strategies. Hidden curriculum is perceived by the upper secondary school students, so it can be said that most of these students are involved in the strategy of teacherstudent interactions (from the three dimensions of hidden curriculum). The dimensions of the hidden curriculum, the strategy of the organizational structure of the school with lowest average (3.04) is known as the lowest factor in the level of student involvement. According to the average obtained from this dimension of the hidden curriculum, this can be concluded that these students had the least involvement in the organizational structure of the school. Therefore, according to the results obtained on this question, it is argued that teachers, most involved in the strategy of solution-oriented. If such a trait is reinforced among teachers, behaviors such as avoiding workrelated stress and problems in the school environment and in relation to co-workers, accepting the other party, respecting the opinions of other teachers and school staff and not imposing their opinions on others, and ultimately improving job performance and efficiency and effectiveness. It is the most characteristic of the teachers of the studied schools.

To investigate the third question: to investigate the relationship between teacher and student interactions with students' academic optimism, the findings showed that the correlation coefficient $(r=0.56)$ at the alpha level $(p=0.01)$ is significant. Thus, it is expected that having the features of the hidden curriculum and having the dimension of teacher-student interactions, increase academic optimism and students' academic growth. In other words, the calculated coefficient of determination shows that the component of teacher-student interactions explains 0.26 of the variance of the academic optimism variable. This result shows that students' academic achievement and academic optimism and having this feature makes them transform and introduce students as a researcher and creative person. Schools that have strategies for using the hidden curriculum, promote growth and creativity and a sense of curiosity, and as a result, increase students' social education and optimism and creativity. Students who are supported by teachers in an environment that uses such programs, enter the learning process correctly, have a high commitment to learning, are more satisfied with the classroom, have a clearer vision of the future of work, have higher social education, and have better academic performance than other students.

The results of inferential tests and statistical analysis on the fourth question: the relationship between school social climate and students 'academic optimism, indicated that there 
is a direct and positive relationship between school social climate and students' academic optimism $(r=0.51)$. This relationship is significant at the alpha level of 0.01 . In this way, by increasing and applying the social atmosphere of the school, increase students' academic optimism. Also, the calculated coefficient of determination shows that the school social atmosphere component explains 0.23 of the variance of the students' academic optimism variable. In explaining this finding, schools that promote the hidden curriculum structure and its dimensions in their schools, provide trust and support for students to improve their education and continue their academic and scientific optimism. In such a situation, students trust, and so does trust in students and parents. In explaining this finding, it can also be acknowledged that the hidden curriculum can have benefits such as providing a context for identifying students' problems, and identifying their solutions. With the hidden curriculum, teachers can find the problems created for students in understanding the lesson and change their teaching accordingly through the report they receive from their teaching. Students can think through a hidden curriculum with classmates and friends who have such learning difficulties and lack of confidence in thinking, and discuss to find a suitable solution. The teacher can also use the hidden curriculum through the teaching report to identify students who are not enough motivated to participate in the classroom and motivate and think in different ways.

Results on the fifth question: the relationship between school organizational structure and students' academic optimism, it shows that the correlation coefficient $(r=0.032)$ and the significance level of 0.36 indicate the absence of a significant relationship between the two variables. This means that schools and students' characteristics of the school's organizational structure do not affect their academic optimism. In other words, the findings of the present study show that it can be considered in educational organizations such as schools. It seems that the age of the students can affect the results of this finding. So that most research in this field, indicates a significant and positive relationship between the organizational structure of the school and the creativity and innovation of individuals.

Regarding the sixth question: the relationship between the hidden curriculum and each of the components of students' academic optimism, the dimensions and components of both variables were analyzed using Pearson correlation coefficient. Thus, according to the data obtained from the questionnaire, a correlation matrix was drawn between the dimensions of the hidden curriculum and academic optimism. In the correlation obtained from these dimensions, it was found that there is a positive and significant relationship between the hidden curriculum and all three dimensions of students' academic optimism, which is significant at the alpha level of 0.01 . That is, by increasing the use of the hidden curriculum, the dimensions of scientific optimism increase, and as those dimensions decrease, the scientific optimism of students also decreases. According to the studies conducted during this research, it can be seen that the relationship between hidden curriculum and school effectiveness has been seen in several studies. For example, its effect on students' academic achievement, test performance, homework reminders, grading teacher effectiveness, and students' attitude to learning. Research also shows that students' enthusiasm is related to their intrinsic motivation and vitality to the school curriculum more than other factors. In other words, schools that dynamically present their content and programs with enthusiasm have changed the atmosphere of their classroom and school, and their students report more intrinsic motivation, as well as higher energy in the classroom. As a result, these measures promote learners' academic optimism.

Regression test was used to analyze and evaluate the seventh question of the research: the ability to predict and explain the academic optimism of upper secondary school students by hidden curriculum components. Findings showed that the components of the hidden curriculum have this capability significantly. The results indicate that the overall dimensions of creativity explain 0.28 of the variance of students' academic optimism. Among the components of the curriculum hidden, the teacher-student interaction dimension is a better predictor of students' academic optimism 
outcomes. In this regard, the role of two components of school social atmosphere and teacherstudent interactions is significant. But after the organizational structure of the school, there is no significant variance in students' academic optimism. It seems that the component of teacherstudent interactions in terms of considering the behavioral and metacognitive processes in education, accounts for a large part of the variance. Therefore, one of the important and key factors in academic optimism and the application of hidden curriculum educational strategies, creating a stimulating atmosphere is apt and generally applicable to this type of new curriculum in schools. Schools must create and prepare an environment that fosters the emergence of new ideas through the acquisition of new knowledge in managers and employees, as well as the use of a hidden curriculum to bring about fundamental and desirable changes in its subset. All of this is possible in the hidden curriculum to enhance academic motivation in implementing effective educational strategies, managing the classroom effectively, and involving students in classroom activities. Therefore, it can be said that the hidden curriculum, by providing learning experiences, causes the development of attitudes (three dimensions of cognitive, emotional, and willingness to practice) in students and consequently causes individual, group and organizational effectiveness, as well as scientific and academic motivation.

\section{CONCLUSION}

In the field of students' academic optimism, few studies have been done and in this limited research, many factors have been considered in this field. Undoubtedly, one of the most important factors in the field of students 'academic optimism is hidden curriculum, which can play a major role in nurturing and flourishing students' talents. One of the factors that can empower students in this field is use of hidden curriculum in schools and students' familiarity with it. In this study, the relationship between hidden curriculum and students' academic optimism from the perspective of upper secondary school students was investigated. The findings showed that schools which have hidden curriculum components provide a beneficial environment for learning, increase curiosity and responsibility in students, and increase students' satisfaction with classroom learning environment. In this environment, students themselves choose and control the amount and type of learning, which ultimately leads to better academic achievement and the improvement and development of students' academic optimism. As well, the results indicate that the more hidden curriculum is used in school and among students, their academic optimism also increases. Also, when schools have a favorable structure, the level of students' trust increases and increases academic optimism and academic achievement among students. Students and schools that use effective methods to enhance learners' learning, including strengthening the hidden curriculum and promoting it in their schools, build trust and support for students and thus their academic optimism. In this situation, students trust teachers and administrators, and so do educational effectiveness and academic optimism.

Authors' Contributions: Fatemeh Kariman: designed the study, prepared the plan, wrote the first draft of the manuscript and edited the final version. Soolmaz Nourabadi: designed the study, prepared the plan, wrote the first draft of the manuscript and edited the final version. All authors have read and approved the final version of the manuscript.

Ethics Approval: Not applicable.

Acknowledgments: Not applicable. 


\section{REFERENCES}

Alikhani, M. \& Mehr Mohammadi, M. (2014). Investigating the Unintended Consequences of the Hidden Curriculum due to the Social Atmosphere of High Schools in Isfahan and Providing Solutions to Reduce its Negative Consequences. Journal of Daneshvar Behavior, 16, 23-37.

Amini, Susan \& Saeedkia, Abdullah (2018). Investigating the Effectiveness of Hidden Curriculum on Intellectual Capital of Students in District 3 of Tehran. Movement Quarterly, 41, 5-17.

Anderson, T. (2017). Revealing the Hidden Curriculum of E-Learning. Distance Education and Distributed.

Andrew, G. C., Mccauley, K. D., Gardner, W. L., Galer, C. E. (2015). A Meta Analytic Review of Authentic and Academic Optimism. Quarterly. doi:10.1016/j.leaqua.2016.02.006.

Dekle, D. (2018). The Meta Curriculum: Guarding the Golden Apples of University culture. Phi Kappa Phi Forum; Honor Society of Phi Kappa Phi.

Fassih, Bashir (2016). Investigating the Effect of Hidden Curriculum on Students' Creativity. M.A. Thesis of Allameh Tabatabaei University of Tehran.

Jasovsky, J. H (2016). New Under the Sun: Transformational Leadership from a Historical Perspective, Management Decision, 41(1), 85-95.

Kulophas, W. K (2014). Academic Optimism of Schools: A Force for Student Achievement. American Educational Research Journal, 43(3), 425-446.

Lipman, M. (2019). Critical Thinking- What Can It Be? Educational Leadership, 46(1).

Mirtrabi, Mahdieh Sadat (2017). Investigating the Factors Affecting the Academic Optimism of Secondary School Students in Tehran. Quarterly Journal of New Approach in Educational Management, 5, 115-134.

Norouzi, Reza Ali \& Jannat Fereyduoni, Tayebeh \& Mashkaliyeh, Maryam (2014). Investigating the Relationship between the Components of the Hidden Curriculum and the National Identity of Secondary School Students. Research in Curriculum Planning, 15, 111-141.

Peterson, C. (2016). The Future of Optimism. Journal of personality and social psychology, 32(3), 411-123.

Received: 01 June 2021 | Accepted: 22 June 2021 | Published: 21 July 2021

This is an Open Access article distributed under the terms of the Creative Commons Attribution License, which permits unrestricted use, distribution, and reproduction in any medium, provided the original work is properly cited. 